\title{
Application of the SWAT Model for Evaluating Discharge and Sediment Yield in the Huay Luang Catchment, Northeast of Thailand
}

\author{
Haris Prasanchum $^{1 *}$, Sasithum Phisnok ${ }^{1}$ and Sanhawit Thinubol ${ }^{2}$ \\ ${ }^{1}$ Faculty of Engineering, Rajamangala University of Technolgy Isan, Khon Kaen Campus, Khon Kaen, 40000, Thailand \\ ${ }^{2}$ Regional Irrigation Office 5, Royal Irrigation Department, Udon Thani, 41000, Thailand
}

\begin{abstract}
The climate change and insufficient data of the discharge and sediment yield in the catchment system are the main cause of the conflict amongst the consumers. The application of a semidistributed hydrologic model and geographic information system can be a solution to this conflict. This study implemented the SWAT model to estimate the discharge and sediment yield in the Huay Luang Catchment, Northeast of Thailand. The accuracy of the model was affirmed and compared with the data from the Kh103 observed station during 2008-2016 via SWAT-CUP. The study outcome suggested that the SWAT model provided favourable results compared to the observed data where $\mathrm{R}^{2}$, NSE, and PBIAS of the discharge were $0.79,0.77$, and $-18.1 \%$ respectively and those of the sediment yield were $0.68,0.65$, and $-22.7 \%$ respectively. Additionally, the quantitative analysis on 22 sub-catchments as the spatial map derived from the Watershed Delineation indicated that both discharge and sediment yield during 2008-2011 were higher than the regular values by 35.9\% and 109.6\% consecutively, whereas during 2012-2015 were lower than the regulars by $22.4 \%$ and $45.4 \%$. In the raining season, more than $50 \%$ of the sub-catchments demonstrated 9-20 cubic meter per second of the discharge and 1,000-5,000 tons of the sediment yield, while during the drought season, both volumes in most of the catchments indicated less than 6 cubic meter per second and 1,00o tons, respectively. These happened due to the changes of the rainfall each year. Hopefully, the result and spatial information from this study could be a great contribution to the water resource management and development in any catchment with insufficient data.
\end{abstract}

Keywords: discharge; sediment yield; Huay Luang Cathcment; SWAT; SWAT-CUP

\section{INTRODUCTION}

Nowadays, Thailand has launched a strategy to support the general economic development such as agriculture, industry, as well as the increasing number of the population; therefore, there is higher demand for the land use for cultivating to increase the product quantity and expanding the industrial estate and residence area. This demand has yielded several changes on the ground surface along with the rapidly growing rate of the land use (Faksomboon \& Thangtham, 2017), e.g. the forest intrusion or changes of crop types (Roslee \& Sharir, 2019). It is critically expected that these problems would impact the hydrological system within the catchment areas; for example, during the raining season, the discharge following downwards the main stream and the sediment yields washed out from the ground surface would be changed so that the water quantity and quality was unfavourable for water resource management in catchment areas (Arnold et. al., 1998; Wuttichaikitcharoen \& Babel, 2014; Ghani et al., 2019) as well as decreasing the flow rate and increasing the contamination of raw water. As a consequence, the measurement and estimation of the discharge and sediment yields within the streams could be the important data for creating the water resource development plan. Still, there has been an obstruction in collecting and filing the data from the responsible organizations such as the Royal Irrigation

*Corresponding author's e-mail: haris.pr@rmuti.ac.th 
Department or the Department of Water Resources due to the problems in purchasing the advanced measurement tools or the insufficient budget for maintenance. Accordingly, the hydrological model could be another useful choice for the data analysis on the discharge and sediment yield at the gauge station with insufficient data or limited period of time for data recording. This model is also time-saving and cost-saving for the operation.

In the past, analysis of discharge and sediment yield in catchment areas has been carried out using hydrologic models, which are available in various forms, such as VIC, TOPMODEL, HBV or MIKE-SHE, all of which are based on water balance principles (Nourani et. al., 2011; Lasen et. al., 2014; Oubeidillah et. al., 2014; Ali et al., 2018;). However, each type of model will have different suitability depending on the purpose to be analyzed. For example, VIC is suitable for wetland areas and water management for agricultural areas (Devi et al., 2015). MIKE-SHE has a huge demand for importing physical data, which is a limitation for small river catchments that lack data (Devi et al., 2015). While sediment quantity studies using models such as GeoWEPP, SEDMODL or RUSLE (Maalim et. al., 2013; Parsakhoo et al., 2014; Ganasri \& Ramesh, 2016) have a lot of basic operations or require limited specific data such as satellite imagery.

Based on the literature review, each of the models has its distinctive feature that differently matches with specific objectives and usages and requires different types of input. Each also has its own method for parameter adjustment to provide the most favourable results. To do so, the model needs a huge number of the input and highly delicate data so it needs to work with a high-performing computer (Xia et al., 2019) that match with the data calculation time. Unfortunately, some catchment contains insufficient input due to the lack of data, shortage of budget for digital file creation, as well as incomplete primary data. Besides, some forms of quantitative data from the model can be displayed as either numbers or graphs, so it may need more specific computer facilities to present the spatial data analysis. In case of the insufficient input, an engineer or researcher may use a hydrological model that can quickly calculate the data and present different types of data from a single calculation. They may apply it with GIS to obtain the hydroinformatics data (Vojinovic \& Abbott, 2017) for the stakeholders to effectively solve the problematic water resources (Zardari et al., 2019). As a result, a hydrological model with upgraded functions and an ability to provide a favourable outcome for the catchment with limitations or incomplete data is considered necessary.

Currently, the estimation of sediment and discharge in the regional catchment using the Semi-Distributed Model (SDM) is widely attractive because the results obtained from the model can reflect the hydrological changes according to the physical characteristics of the catchment area such as land use, area slope and the local climate. The SWAT model is one of the most widely semi-distributed hydrologic models in the world (Cai et al., 2012), which has been applied for the study, analysis, and evaluation of sediment and discharge problems in the catchment, such as predict the sediment yield and in small catchments that are affected by land use changes due to increased population and construction demand (Cai et. al., 2012; Huang \& Lo, 2015; Zuo et al., 2016), estimation of sedimentation from surface erosion (Son et al., 2015; Vidula \& Sushma, 2017), simulated discharge in the case of catchments lacking gauge stations and spatial data (Mango et al., 2011).

At this point, Huay Luang is a sub-catchment of Khong Catchment in the northeast of Thailand where the discharge coming along with the sediment yield has been a critical problem that negatively affects the water resource management. This varied the discharge efficiency and sediment yield is expected to affect the carrying capacity of the streams. Consequently, this research aimed to apply the SWAT model for data evaluation on the discharge and sediment yield in ungauged areas through classification as a sub-catchment that covers the Huay Luang Catchment. It was also expected that the methodology and outcome of this research would be another approach to support the responsible organization or person in deciding on the water resource development planning in any target catchments either at current state or in the future.

\section{MATERIALS AND METHOD}

\section{A. Study Area}

For the target area, in this study, the Huay Luang Catchment is a sub-catchment of Khong Catchment in the northeast of Thailand covering about $3,350 \mathrm{~km}^{2}$ of area where the Huay 
Luang River flows from the southwest to the northeast as presented in Figure 1(a). The annual average rainfall is 1,300 $\mathrm{mm}$. The rainfall data was taken from 7 raingauge stations separately located throughout the target catchment whereas the climate data was obtained from the Udon Thani Station located at the midst part of the catchment.

The observed discharge and sediment yield were taken from the Kh103 Station located in the midst of the area were later compared with the result of the model. The majority of the population is engaged in agriculture using rainwater and irrigation systems. The most commonly planted crops are rice, cassava, sugarcane, and plantations. However, the problem of intrusion in the upstream areas, the expansion of communities near the water resource has expanded rapidly, changes in cultivation patterns and global climate change in the past 10 years are expected to directly affect the volume of discharge and sediment yield in the Huay Luang Catchment.

\section{B. SWAT Model}

The SWAT (Soil and Water Assessment Tool) (Arnold et al., 1998) is a hydrological model developed for evaluating sediment change, discharge and water quality in rivers that are affected by climate and land use changes in the past, present and future forecasts (Mango et al., 2011). The model can divide processing at multiple catchments at various levels, such as creating sub-catchments in the main catchments, including calculations that show daily and monthly results and long period of time using water balance equations to be considered based on variables from the hydrological process, as illustrated in the Equation (1).

$$
S W_{t}=S W_{0}+\sum_{i=1}^{t}\left(R_{\text {day }}-Q_{\text {surf }}-E_{a}-W_{\text {seep }}-Q_{q w}\right)
$$

where $S W_{t}$ is final soil water content $(\mathrm{mm}), S W_{o}$ is initial soil water content (mm), $t$ is time (day), $R_{\text {day }}$ is rainfall on Day $i$ (mm), $Q_{\text {surf }}$ is surface water content on Day $i(\mathrm{~mm}) . E_{a}$ is evapotranspiration content on Day $i(\mathrm{~mm}), W_{\text {seep }}$ is underground seepage content on Day $i(\mathrm{~mm})$, and $Q_{g w}$ is underground water content flowing back to a stream on Day $i$ (mm) (Sajikumar \& Remya, 2015).

Evaluation of sediment quantities using the SWAT model used imported soil data in the model and determining the physical properties of the soil as it affects the movement of water and air, which is important for water circulation in each hydrologic response unit. The important elements that affect sedimentation in various streams include: 1) the volume and the intensity of rainfall; 2) the characteristics of soil and rocks in the catchment; 3 ) the characteristics of the soil cover, for example, in case of the evergreen forest, there will be sediment less than the deciduous forest; 4) the type of land use, for example, if the area is always planted with ground cover plants, erosion rates will be reduced; 5) topographical conditions, such as if the slopes are very steep, the water will flow more likely to cause erosion and; 6) other elements such as size, shape and condition of use of the catchment. For the equation used to assess sediment quantity in the SWAT model, the model applied the Modified Universal Soil Loss Equation (MUSLE) (Petsountang \& Jirakajonhkool, 2012) as exposed in Equation (2).

$S=11.8\left(Q_{\text {surf }} q_{\text {peak }}\right)^{0.56}$ K.LS.C.P

Where $S$ is the total amount of sediment that flows out of the cathcment (metric tons), $Q_{\text {surf }}$ is the amount of water $\left(\mathrm{m}^{3}\right)$, $q_{\text {peak }}$ is the maximum flow ( $\mathrm{m}^{3}$ per second), $K$ is the factor of soil erosion stability is specific to each layer of the soil, $L S$ is the length and slope factor, $C$ is the plant management factor, $P$ is the control factor for the erosion of soil, 11.8 and 0.56 are the data constant values for each rainstorm applied to GIS.

\section{Data Collection}

The data collected and used with the SWAT model consisted of the Digital Elevation Model (DEM) with a resolution of $30 \times 30 \mathrm{~m}^{2}$, the soil types map, the land use map, the daily climate data consist of; rainfall, maximum and minimum temperatures, relative humidity, solar radiation, and wind speed, as well as the discharge and sediment yield from the Kh103 Station. Particularly, the land use data was surveyed in 2015 classified into 9 groups in which most of the land was used for rice field, sugarcane, cassava, generic agriculture, and urbanization area (see Figure 1(b)).

The soil type data was assembled by the Land Development Department of Thailand in 2015, accordance with the soil classes of the SWAT model based on the Food and Agriculture Organization (FAO, 2006) textural classes including 5 soil groups: most of them were in Sandy loam, sandy loam clay (SL, SCL) and Clay (C) in north part (see Figure 1(c)). All of these data for input to the SWAT model and for the model 
performance evaluation were presented clearly in Table 1.

Table 1. Spatial data and observed discharge data for the SWAT model performance evaluation

\begin{tabular}{|c|c|c|c|}
\hline Data types & Period & Scale & Source \\
\hline \multicolumn{4}{|c|}{ Spatial data (model input) } \\
\hline DEM & 2015 & $30 \times 30 \mathrm{~m}$ & \multirow{4}{*}{ LDD } \\
\hline River map & 2015 & \multirow{3}{*}{$1: 50,000$} & \\
\hline Soil types & 2015 & & \\
\hline Land use & 2015 & & \\
\hline Climate & 2008-2016 & Daily & TMD \\
\hline
\end{tabular}

Observed sediment and discharge

(model performance assessment)

\begin{tabular}{l|c|c|c}
\hline Kh103 & 2008-2016 & Daily & RID \\
\hline
\end{tabular}

\section{Remarks;}

LDD : Land Develop Department

TMD : Thai Meteorological Department

RID : Royal Irrigation Department

\section{Sub-Catchment Modeling and HRUs Analysis}

The study area, Huay Luang Catchment was defined from the DEM input used for the evaluation on the physical use types characteristics of the sub-catchment; meanwhile, the land and the soil types were defined by inserting the land use map and soil types map into the SWAT model so that they could be linked with the data from the study area. The determination of Hydrological Response Units (HRUs) (Cai et. al., 2012; Noh et al., 2019) was the stage to define the resolution of the catchment unit in which the sub-catchment normally contains different HRUs, e.g. those that were consistent with the types of land use and land cover, the soil groups, the land slope, etc.

Regularly, these HRUs are diversified by each specific area as well as by the hydrological conditions based on the meteorological factors of each HRUs. Indeed, the HRUs determination had further impact on the model accuracy estimation during the sensitivity analysis of hydrological parameters. In term of the climate input, there were 5 key parameters including: 1) rainfall; 2) maximum and minimum temperatures; 3) relative humidity; 4) wind speed; and 5) solar radiation. These parameters were daily data that was presented in Table 1 arranged in a favourable order for the SWAT model.

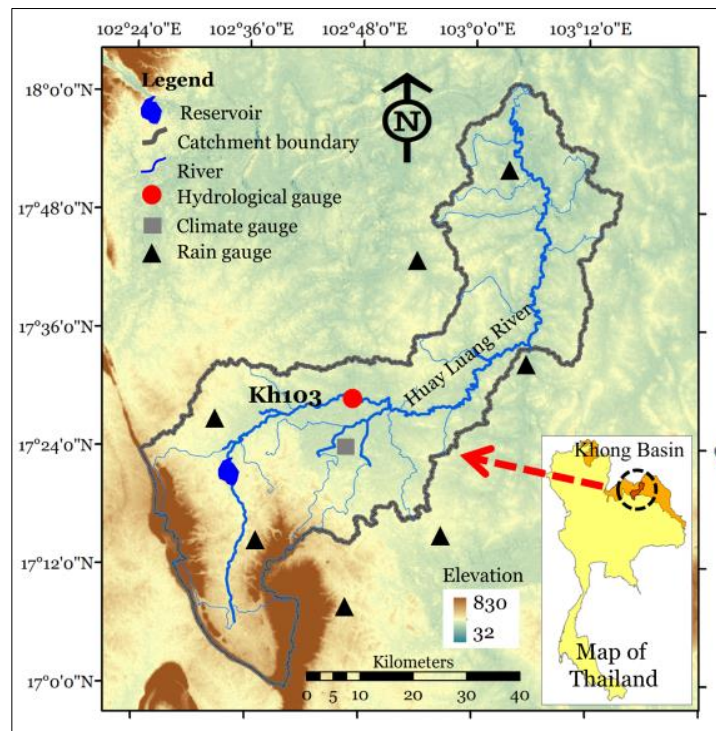

(a)

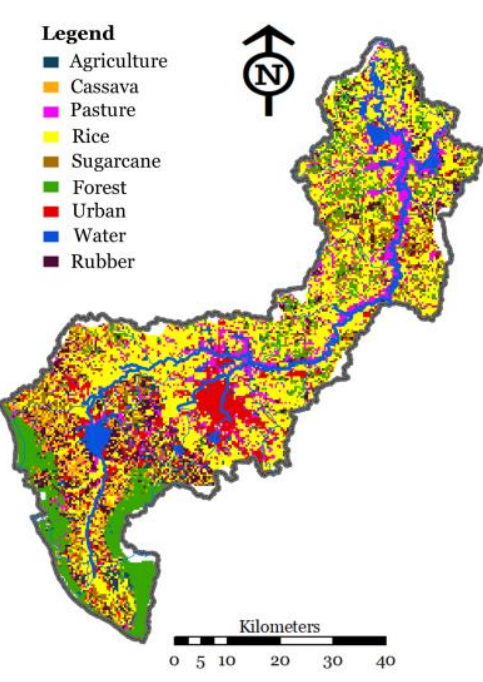

(b)

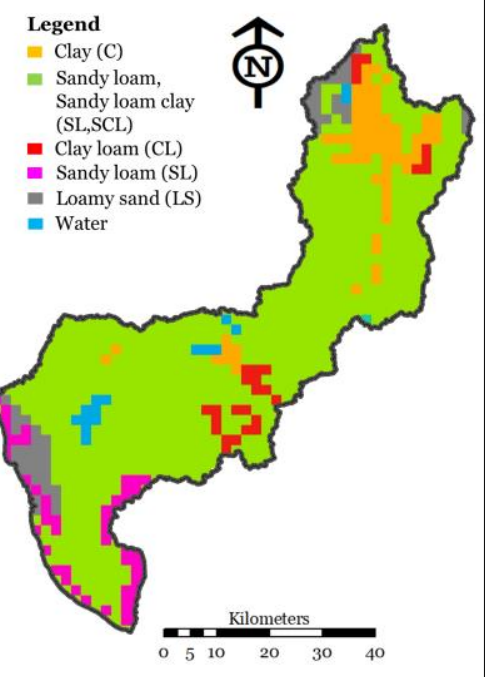

(c)

Figure 1. Spatial data of the Huay Luang Catchment, (a) study area and DEM, (b) land use types map and (c) soil types map 


\section{E. Model Calibration and Validation using SWAT-CUP}

The estimation on the SWAT model's performance could be managed by calibration and validation (Abbaspour et al., 2015) on the discharge and sediment yield derived from the model along with the sensitivity analysis via SWAT-CUP (SWAT Calibration and Uncertainty Procedure) (Djebou, 2018; Faiza et al., 2018) on the hydrological parameters with an impact on the discharge and sediment yield. SWAT-CUP is designed to work with the SWAT model, which increases the efficiency, flexibility, and shorten the time period for sensitivity variable analysis when compared to previous techniques, such as manual correction by trial and error. The result of adjusting the sensitivity parameter obtained from SWAT-CUP will be a guideline or an appropriate solution for the calibration and validation between the calculation results from the SWAT model and data from the hydrological gauge station

The operation has the option of using 5 optimization techniques, which include: 1) Generalized Likelihood Uncertainty Estimation (GLUE); 2) Particle Swarm Optimization (PSO); 3) Parameter Solution (Parasol); 4) Mark Chain Monte Carlo (MCMC); and 5) Sequential Uncertainty Fitting (SUFI-2). For this study, we have considered using the SUFI-2 technique in operations. The strength of the SUFI-2 is that it requires the least amount of sensitivity parameters, but still provides the best results (Ayivi \& Jha, 2018; Abbaspour et al., 2007), as well as showing the widest range of sensitivity parameter results compared to other techniques (Yang et al., 2008). After an optimum coefficient had been defined, it would replace the coefficient of a parameter in the SWAT model in order to make the calculated discharge and sediment yield close to the result from the gauge station the most. This data was taken from the Kh103 Station where the data was monthly recorded during January 2008-December 2016.

Specifically, in this study, several statistical indexes were applied to affirm the model accuracy during calibration and validation procedures to test the goodness of fit between monthly observed and simulated values. These indexes were significant to examine and impose the exactitude of the SWAT model simulations. These indexes consist of; Coefficient of Determination $\left(\mathrm{R}^{2}\right)$, Nash-Sutcliffe Efficiency coefficient (NSE), and Percent Bias (PBIAS) (Yang et al., 2014), as described in Equations (3)-(5), respectively. The ordinary performance level for approved statistics in monthly time step of the model simulation can be divided into four levels (Zang et al., 2019) as explained in Table 2.

$$
\begin{gathered}
R^{2}=\left(\frac{\sum_{i=1}^{n}\left(O_{i}-O_{a}\right)\left(S_{i}-S_{a}\right)}{\sqrt{\sum_{i=1}^{n}\left(O_{i}-O_{a}\right)^{2}} \sqrt{\sum_{i=1}^{n}\left(S_{i}-S_{a}\right)^{2}}}\right)^{2} \\
\text { NSE }=1-\frac{\sum_{i=1}^{n}\left(O_{i}-S_{i}\right)^{2}}{\sum_{i=1}^{n}\left(O_{i}-O_{a}\right)^{2}} \\
\text { PBIAS }=\frac{\sum_{i=1}^{n}\left(O_{i}-S_{i}\right)}{\sum_{i=1}^{n}\left(O_{i}\right)} \times 100
\end{gathered}
$$

Where $i$ was the data order, $n$ was number of total data, $O_{i}$ was the data from gauge station at time $i, O_{a}$ was the average of total data from gauge station, $S_{i}$ was the average of the data from simulated at time $i$, and $S_{a}$ was the average of the data from simulated.

Table 2. Ordinary performance levels for approved statistics in monthly time step

\begin{tabular}{ccccc}
\hline Level & $\mathbf{R}^{2}$ & NSE & PBIAS \\
\cline { 3 - 5 } & & & Discharge & Sediment \\
\hline Very good & $0.80<\mathrm{R}^{2} \leq 1.00$ & $0.75<\mathrm{NSE} \leq 1.00$ & $\mid$ PBIAS $\mid<10 \%$ & $\mid$ PBIAS $\mid<15 \%$ \\
Good & $0.70<\mathrm{R}^{2} \leq 0.80$ & $0.65<\mathrm{NSE} \leq 0.75$ & $10 \% \leq \mid$ PBIAS $\mid<15 \%$ & $15 \% \leq \mid$ PBIAS $\mid<30 \%$ \\
Satisfactory & $0.60<\mathrm{R}^{2} \leq 0.70$ & $0.50<\mathrm{NSE} \leq 0.65$ & $15 \% \leq|\mathrm{PBIAS}|<25 \%$ & $30 \% \leq \mid$ PBIAS $\mid<55 \%$ \\
Unsatisfactory & $\mathrm{R}^{2} \leq 0.60$ & $\mathrm{NSE} \leq 0.50$ & $\mid$ PBIAS $\mid \geq 25 \%$ & $\mid$ PBIAS $\mid \geq 55 \%$ \\
\hline
\end{tabular}




\section{RESULTS AND DISCUSSION}

\section{A. Sensitivity Parameter Analysis}

The parameter sensitivity analysis was performed via SWATCUP using SUFI-2 in which 500 calculation rounds were defined, as 8 and 4 parameters affecting the discharge and sediment yield were also prescribed respectively. The optimum outcome making the calculated result mostly similar to the discharge and sediment yield measured at the gauge station were described in Table 3. In terms of using SUFI-2 to analyze the order of sensitivity parameters, the basic principle of analysis was based on $t$-stat and P-value. When the results indicate the highest $t$-stat, the parameter has the best relationship (when + and - were excluded), whereas P-value shows the significance of sensitivity. If Pvalue was close to zero, that parameter was most significant. The result from $t$-stat and P-value impacted the discharge and sediment yields based on the sensitivity order presented in Table 3.

Both $t$-stat and P-value indicated that SOL_AWC and USLE_P were mostly related to the model's sensitivity (Regular P-value $<=0.05$ ). No.3 -5 were the parameters related with the groundwater including GW_REVAP, GWQMN, and ALPHA_BF, and No.6-7 were the sedimentrelated parameters including SPCON and SPEXP. The rest were $\mathrm{ESCO}$, the parameter related to ground-surface infiltration, followed by No.9-10, the evaporation in shallow aquifer and groundwater parameters including REVAPMN and GW_DELAY. Finally, LAT_SED and CN2 are displayed in the No.11 and 12 positions.

According to the parameter adjustment via SWAT-CUP, the analysis on the sensitivity parameter between the dischargerelated and sediment yield-related parameters indicated that the surface discharge (No.1: SOL_AWC) and the soil loss (No.2: USLE_P) were amongst the top influential parameters (Khalid, et al., 2016; Hosseini \& Khaleghi, 2020) and this implied that the surface discharge directly had a significant relation with the sediment yield (Khelifa et al., 2017; Worku et al., 2017) connected through the variables related to the evaporation of the groundwater (No.3-5) and the sediment in the rivers (No.6-7), respectively.

\section{B. Model Calibration and Validation}

The complete data of discharge and sediment yield from the Kh103 Station between 2008-2016 is considered to be compared with the calculation results from the SWAT model. Due to the limitation of the data from the observed station is only 9 years (sediment yield has only 8 years-no recorded in 2014), as well as the annual volume of discharge and sediment yield that has changed to the extreme during the considered period. Figure 2 shows the total annual volume data of both variables (recorded from the observed station) which indicates the year 2008-2011, and both variables have normal-high volume (in 2011 Thailand has the Great Flood event). On the contrary, between 2012-2016, both volumes were lower than average. To make it reasonable to calibrate between the model and the observed values, and to cover the fluctuate situation was described earlier. The selection of the calibration period is used during 2011-2016 (6 years) in order to cover between high and low volume events. While the validation will be between 2008-2010 (3 years) which covers the near normal and high volume.

The calculated result from the SWAT model compared with the data at the Kh103 Station recorded during 2008-2016 was shown in Table 4. The results of the model accuracy evaluation of both discharge and sediment yield have suggested that the overall values of $\mathrm{R}^{2}$ is within the criteria "good" (0.79 and 0.68), NSE is "good" (0.77 and 0.65) and PBIAS is "satisfactory" (discharge, -18.1\%) and "good" (sediment yield, -22.7\%). For compatibility between the model results and the actual observed values of discharge and sediment yield at the Kh103 Station, the monthly hydrograph is shown in Figure 3(a) and (b), respectively. The results indicated that the SWAT model can be applied to assess discharge and sediment yield for the Huay Luang Catchment with acceptable accuracy. 
Table 3. Calibrated sensitivities parameters and fitted values using SUFI-2 from SWAT-CUP

\begin{tabular}{|c|c|c|c|c|c|c|}
\hline Rank & Parameters & Description & $\begin{array}{l}\text { Fitted } \\
\text { Value }\end{array}$ & $\begin{array}{l}\text { Adjust } \\
\text { Range }\end{array}$ & $t$-stat & P value \\
\hline 1 & V_SOL_AWC.sol & $\begin{array}{l}\text { Available water capacity of the } \\
\text { soil layer }\end{array}$ & 0.595 & $0.0-1.0$ & 2.71 & 0.00 \\
\hline 2 & V_USLE_P.mgt & USLE equation support (P) & 0.00125 & $-0.2-0.2$ & -2.02 & 0.05 \\
\hline 3 & V_GW_REVAP.gwt & Groundwater "revap" coefficient & 0.1325 & $0.02-0.2$ & -1.51 & 0.13 \\
\hline 4 & V_GWQMN.gwt & $\begin{array}{l}\text { Treshold depth of water in the } \\
\text { shallow aquifer required for } \\
\text { return flow to occur }\end{array}$ & $4,733 \cdot 75$ & $4,250-5,000$ & -1.15 & 0.25 \\
\hline 5 & V_ALPHA_BF.gwt & Baseflow alpha factor & 0.465 & $0.0-1.0$ & 0.80 & 0.42 \\
\hline 6 & V_SPCON.bsn & $\begin{array}{l}\text { Linear parameter for calculating } \\
\text { the maximum amount of } \\
\text { sediment that can be re- } \\
\text { entrained during channel } \\
\text { sediment routing }\end{array}$ & 0.002228 & $\begin{array}{c}0.0001- \\
0.005\end{array}$ & 0.59 & 0.56 \\
\hline 7 & V_SPEXP.bsn & $\begin{array}{l}\text { Exponent parameter for } \\
\text { calculating sediment } \\
\text { reentrained in channel sediment } \\
\text { routing }\end{array}$ & 1.655 & $1.0-2.0$ & 0.39 & 0.69 \\
\hline 8 & V_ESCO.hru & $\begin{array}{l}\text { Soil evaporation compensation } \\
\text { factor }\end{array}$ & 0.115 & $0.0-1.0$ & 0.37 & 0.70 \\
\hline 9 & V_REVAPMN.gwt & $\begin{array}{l}\text { Threshold depth of water in the } \\
\text { shallow aquifer for "revap" to } \\
\text { occur }\end{array}$ & 372.5 & $0.0-500.0$ & -0.30 & 0.76 \\
\hline 10 & V_GW_DELAY.gwt & Groundwater delay & 86.7 & $0.0-500.0$ & -0.26 & 0.79 \\
\hline 11 & V_LAT_SED.hru & $\begin{array}{l}\text { Sediment concentration in } \\
\text { lateral flow and groundwater } \\
\text { flow }\end{array}$ & 98.5 & $0.00-100.0$ & 0.16 & 0.86 \\
\hline 12 & R_CN2.mgt & SCS runoff curve number & 0.142 & $-0.2-0.2$ & 0.13 & 0.89 \\
\hline
\end{tabular}

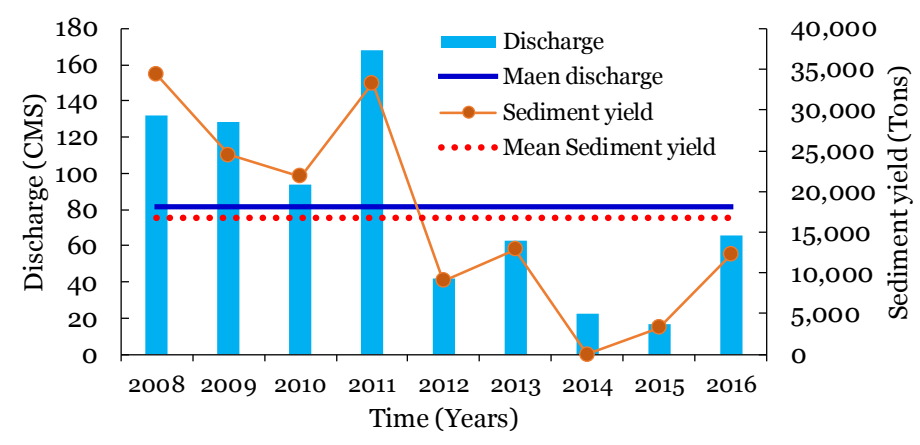

Figure 2. The total of annual volume of discharge and sediment yield during 2008-2016 from the Kh103 Station 


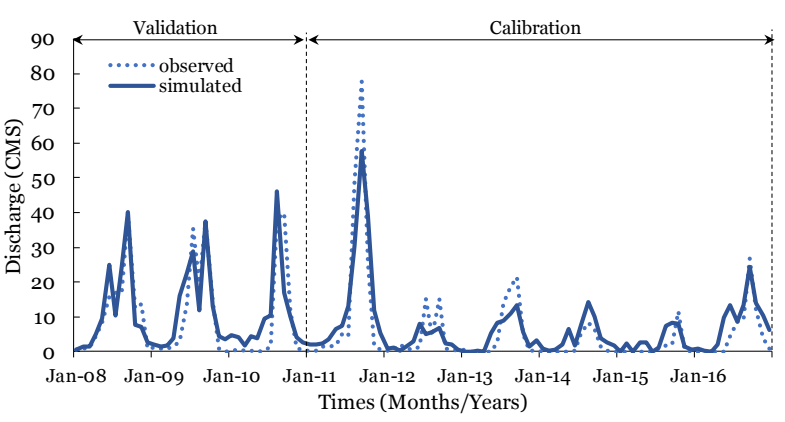

(a)

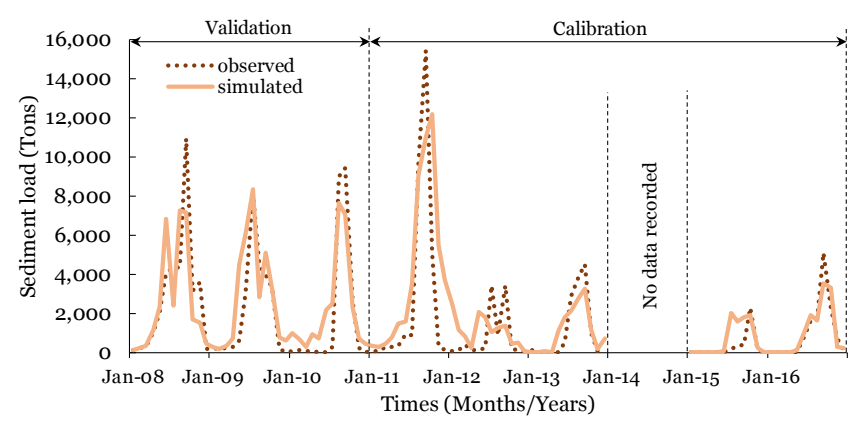

(b)

Figure 3. Comparison of observed and simulation of (a) discharge and (b) sediment yield at monthly time scale

Table 4. Model performance results

\begin{tabular}{lccc}
\hline \multirow{2}{*}{ Range } & \multicolumn{3}{c}{ Assessment index } \\
\cline { 2 - 4 } & $\mathbf{R}^{2}$ & NSE & PBIAS \\
\hline Discharge & & & \\
Calibration (2011-2016) & 0.81 & 0.79 & $-22.8 \%$ \\
Validation (2008-2010) & 0.76 & 0.75 & $-13.1 \%$ \\
Overall (2008-2016) & 0.79 & 0.77 & $-18.1 \%$ \\
Sediment yield & & & \\
Calibration (2011-2016) & 0.64 & 0.60 & $-34.6 \%$ \\
Validation (2008-2010) & 0.73 & 0.72 & $-12.3 \%$ \\
Overall (2008-2016) & 0.68 & 0.65 & $-22.7 \%$ \\
\hline
\end{tabular}

For the next step, the SWAT model that has been adjusted for accuracy in this calculation will be considered to assess the volume of discharge and sediment yield within the $22 \mathrm{sub}-$ catchments (divided by the watershed delineation process of the SWAT model). This evaluation can be carried out in the form of spatial maps, based on the range of colours and quantities to indicate changes in the volume of discharge and sediment yield of the sub-catchment areas and time series.

\section{Spatial Distribution of Discharge and Sediment Yield in Sub-catchment Level}

After the SWAT model had finished calibrating and validating the discharge and sediment yield at the observed station and gained the satisfactory results, both values from all 22 subcatchments after the watershed delineation were later summarized to define the annual averages and the input data for the ArcGIS that would be displayed as the spatial distribution map covering the Huay Laung Catchment during 2008-2016 as well as the average during the dry season (November-May) and the wet season (June-October). Figure 4 and 5 show the annual averages of the discharge and sediment yield found in those sub-catchments. In the figures of each year, the monthly averages (bar graph) would be compared with the regular values (the blue dash line represented the discharge and the brown dash line represented the sediment yield).

\section{Discharge}

Regarding the annual discharge average, Figure 4 noted that during 2008-2011, the discharge was higher than the regular value by $35.9 \%-109.6 \%$ (the discharge average in the Huay Laung Catchment is approximately 81.4 CMS per year as shown in Figure 2). Exactly, most of the discharge averages from the sub-catchments in the northeast area and the north could be 9-20 CMS since the monthly averages in the raining season were higher than the regular value, especially in 2009 and 2011 so that there was the Great Flood in the northeast and Thailand. On the contrary, during 2012-2015, it was found that the annual discharge averages from all subcatchments were lower than the regular value by 22.4\%-45.4\%; this could be apparently observed in periods of 2012-2013 and 2015 where the discharge averages from 12-14 sub-catchments, mostly in the southern west, were only 0-3 CMS, and 6-10 sub-catchments in the northeast were 3-6 CMS. Notably, in 2016, the averages were slightly higher than the regular value by $5.4 \%$ where the discharge averages were merely 0-12 CMS. During the dry season from November to May, the averages were lower than $6 \mathrm{CMS}$, whereas, in the wet season from June to October, there was 10 sub-catchments where the averages were 9-20 CMS. In this regard, the subcatchments with high averages were mostly found in the northeast and the north areas since it was a lowland (most of the land was used as the rice field) and the outlet of the Huay Luang Catchment. Differently, the southern west was a steep 
land covered with forest and widely used for growing sugarcane (see Figure 1(a) and Figure 1(b)) so that the discharge there have constantly been low (Sriworamas et al., 2020) all year round.

\section{Sediment Yield}

Figure 5 presents the annual sediment yield averages in the Huay Luang Catchment during 2018-2016 which was $16,817.8$ tons per year when compared to the regular average (see Figure 2); therefore, there were 4 periods from 2008-2011 when the sediment yield was 50\% higher than the regular average; this was consistent with the discharge averages found in the same periods. The sub-catchments with high averages were mostly situated in the north and the northeast. Particularly in 2011 when the sediment yield average was much higher than the regular value by $172.7 \%$ $(45,855$ ton per year), it was found that 10 sub-catchments bears 2,000-6,000 tons of sediment yield or over $50 \%$ of the whole area and it was often found during the wet season lasting to the dry season or from August to December and the next January. Still, the sediment yield averages lower than the regular value could be found in 2012 (-37.5\%) and 2015 $(-39.6 \%)$ where all the sediment yield averages in all subcatchments were lower than 1,000 tons. Additionally, the optimum average was found in 2014 where it was higher than the regular value by only $6.4 \%$.

When considering the averages by seasons, the sediment yield in the dry season did not exceed 1,00o tons in every subcatchment, whereas the averages in the wet season were from 1,000-5,000 tons spreading through 13 sub-catchments. However, the sediment yield with average of 4,000-5,000 tons were typically found at the northern outlet in main catchment, followed by the physical attribute of the area, where the sediment yield was naturally assembled at catchment outlet. On the other hands, in the upstream with the steep area, the sediment yield would be commonly low. Meanwhile, the moderate sediment yield average could be found in the midst of the catchment. In case of the subcatchments with high sediment yield averages, either the measurements or extra activities should be managed for surface water improvement, e.g. soil surface preservation, forest expansion, suitable crop selection, increasing dredging budget, etc.

\section{Analysis of Discharge and Sediment Yield within Sub-catchment Area}

Based on the findings from the previous section, the wet season is a period with the highest discharge and sediment yield, which is consistent with the results of studies in many areas (Zhang et. al., 2016; Azari et al., 2019) that might have some impact on the water resource management (particularly for the sediment yield management); therefore, in this study, magnitude of the discharge and sediment yield that has an impact on the sub-catchment area (Djebou, 2018) is determined by referring to the average in the wet season from 2008-2016. The results of volume comparison in percentages are shown in Table 6 and Figure 6. The compared results in Figure 6(a) indicated that the annual discharge average during the wet season was $166.5 \mathrm{CMS}$ and $38.4 \%$ of the subcatchments (No. 1, 2, 5, 7, 8, and 9) contained 12-20 CMS so that the total average was $77.2 \%$. This mostly happened in the north and the northeast. Meanwhile, $39.3 \%$ of the subcatchments mostly covering the southern west and some parts of the north showed the average lower than 3 CMS that could roughly produce $4.7 \%$ of the discharge, whereas approximately $22.3 \%$ of the sub-catchments mostly in the central part of the area contained a moderate value of 6-12 CMS. Hence, the total average was $18.1 \%$ of the total discharge in the wet season.

As the annual sediment yield average during the same period was 49,768.9 tons. In this regard, the comparison between the area and the average was illustrated in Figure 6(b). It indicated that the majority of $49.3 \%$ of the area showed the sediment yield averages from 2,000-4,000 tons or $64.1 \%$ of the total. The spatial distribution covered the central part spreading toward the upper and lower parts of the catchment. Besides, the minimum sediment yield of $0-2,000$ tons was found in $42.1 \%$ of the area and the total yield was $18.6 \%$. Most of this case was basically found in the upstream in the south and the downstream in the north, meanwhile, the maximum of 4,000-5,000 tons were found in only $8.6 \%$ of the area, but it somehow produced $17.4 \%$ of the total sediment yield average which could be evidently seen at the northern outlet (Sub-catchment No.1 and 2). 


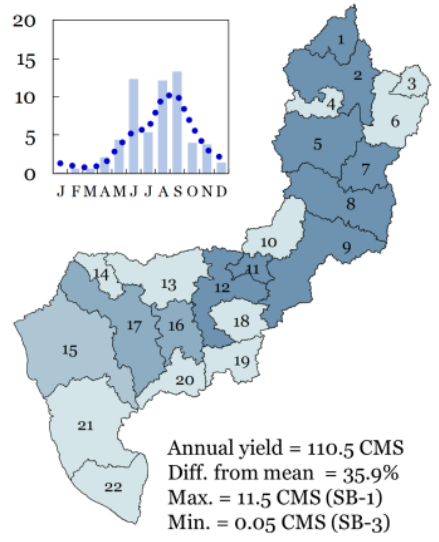

2008

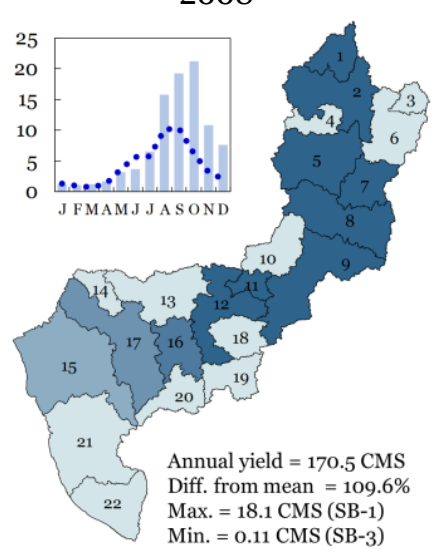

2011

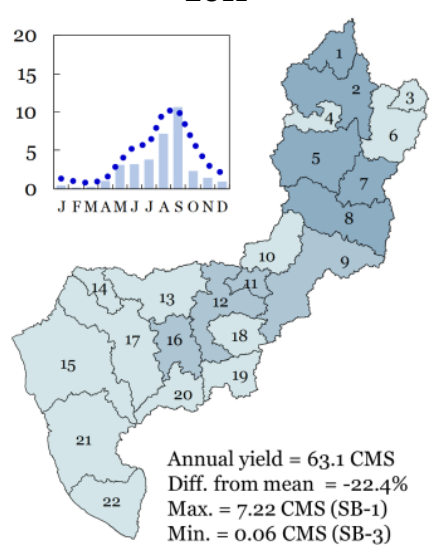

2014

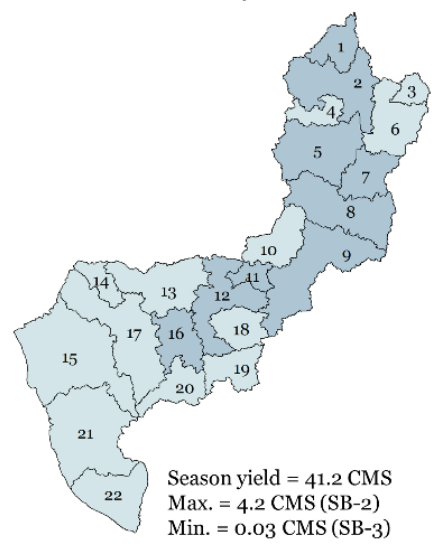

Dry season

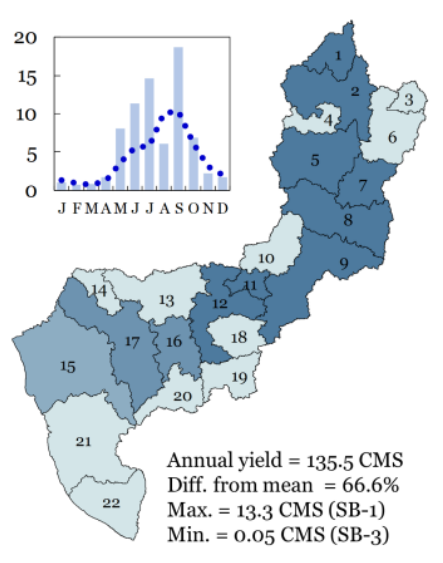

2009

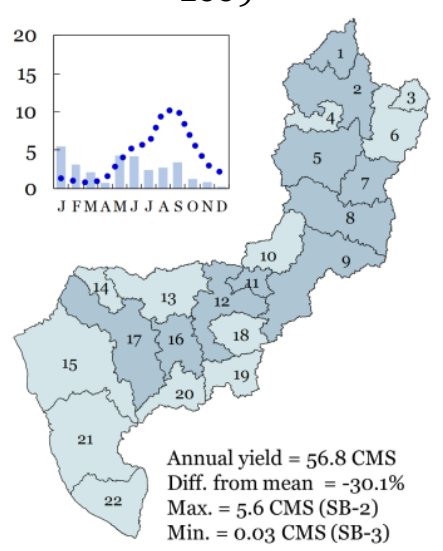

2012

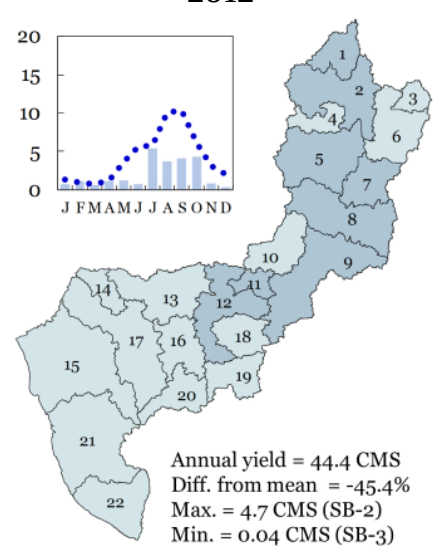

2015

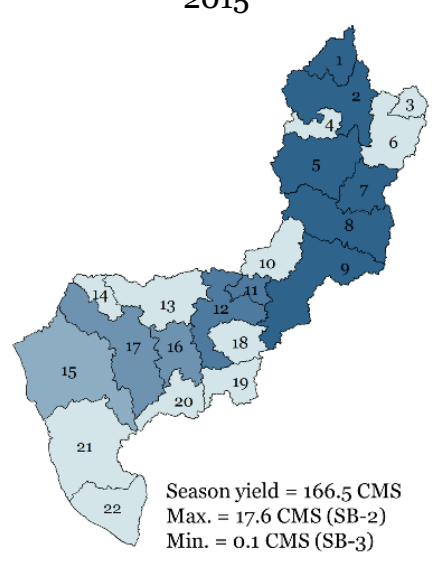

Wet season

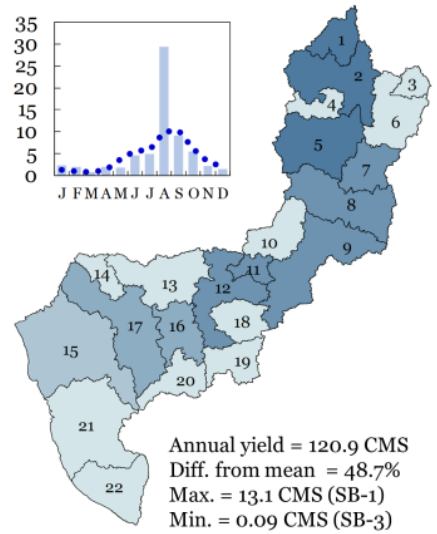

2010

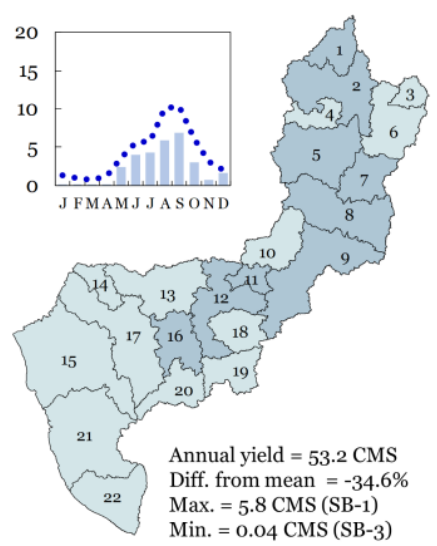

2013

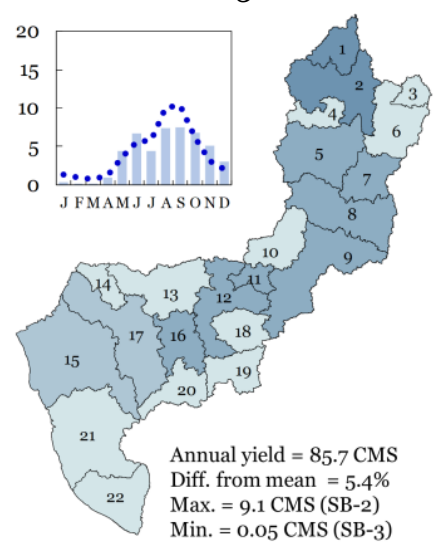

2016

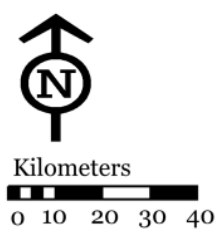

Legend

Discharge (CMS)

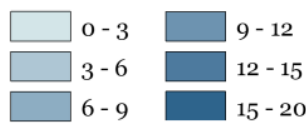

Monthly mean actual

....IIlllilı in the year

..${ }^{\circ} \because$. Monthly mean 9 years

Figure 4. Magnitude of annual discharge across the sub-catchments delineated within the Huay Luang Catchment 


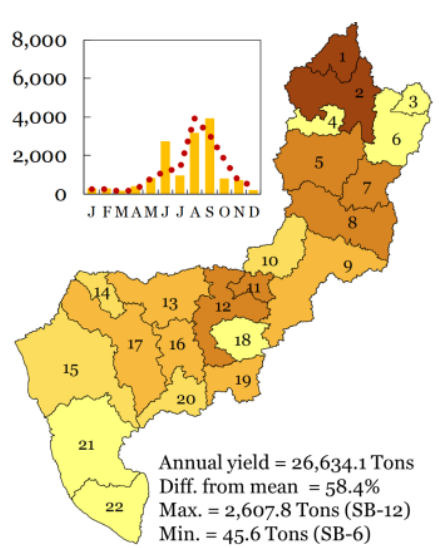

2008

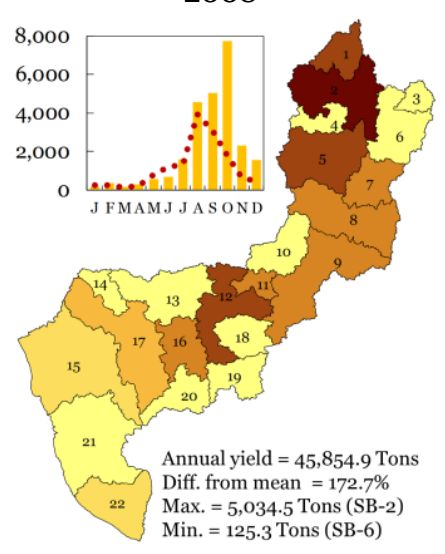

2011

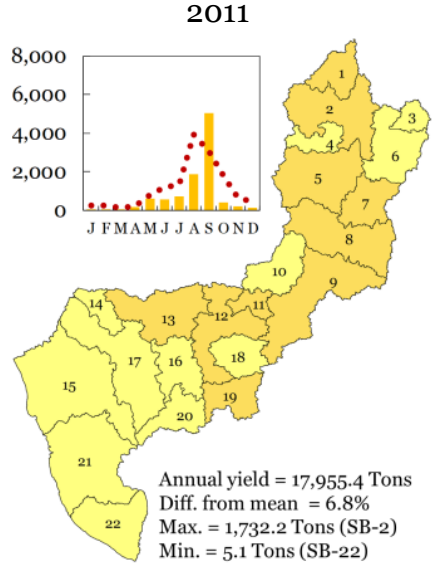

2014

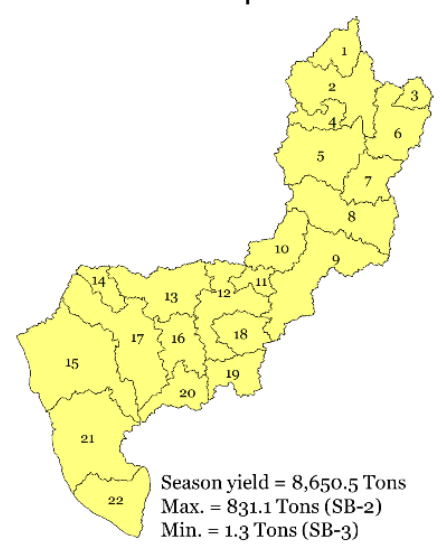

Dry season

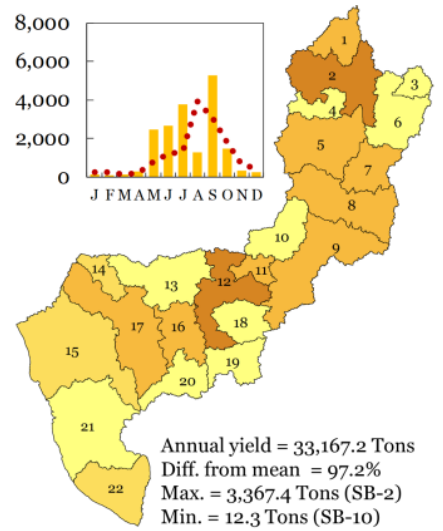

2009

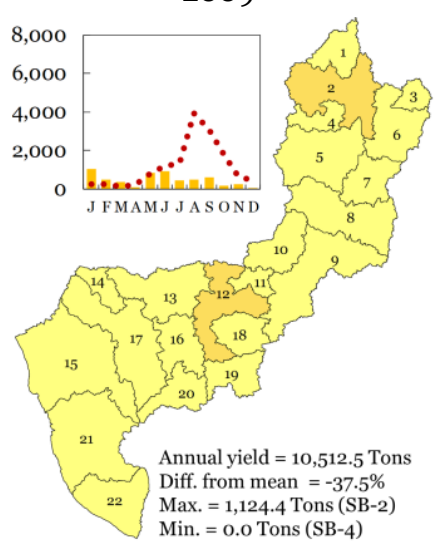

2012

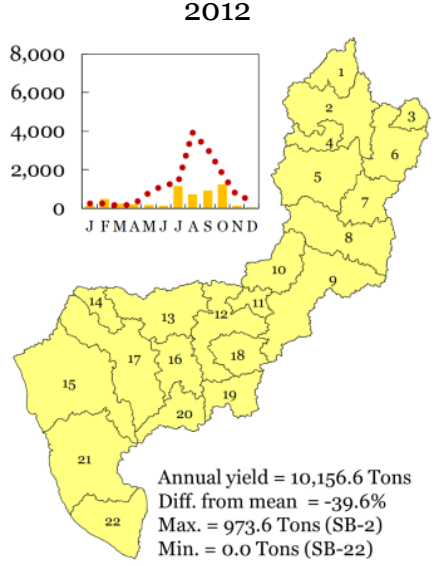

2015

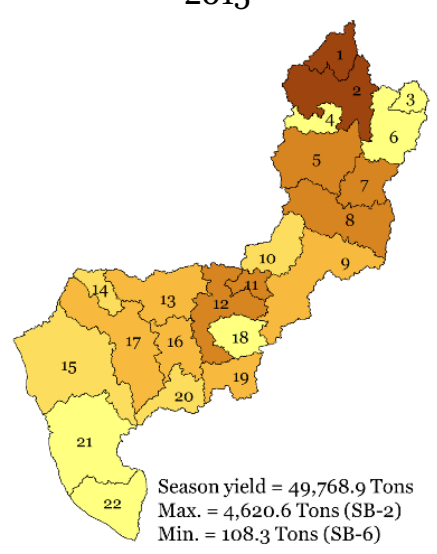

Wet season

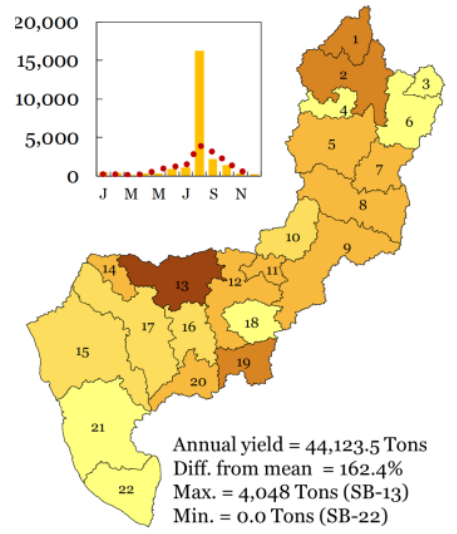

2010

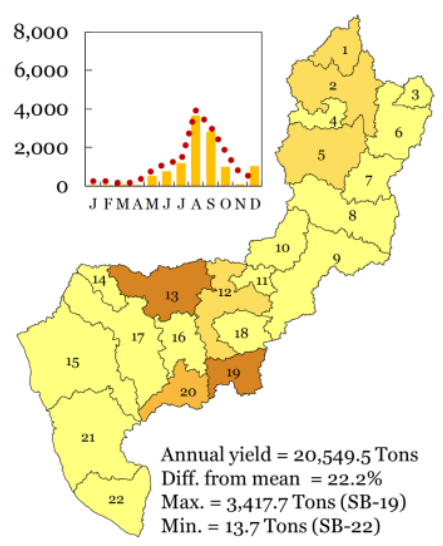

2013

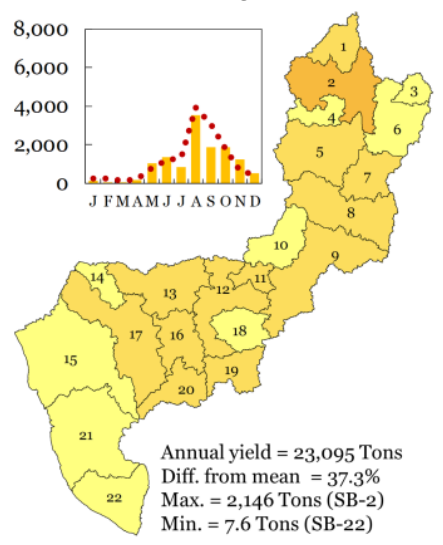

2016

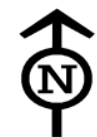

Kilometers

\begin{tabular}{lllll}
\hline 0 & 10 & 20 & 30 & 40
\end{tabular}

Legend

Sediment yield (Tons)

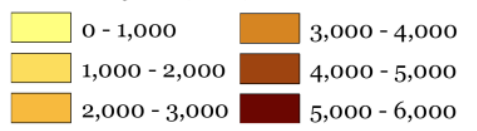

Monthly mean actual

...ullil. in the year

...$\cdots \ddots$. Monthly mean 9 years

Figure 5. Magnitude of annual sedient yield across the sub-basins delineated within the Huay Luang Catchment 
Table 6. Evaluation of discharge and sediment yield of the sub-catchment attended in the catchment area during the wet season

\begin{tabular}{|c|c|c|c|c|c|}
\hline \multirow{2}{*}{$\begin{array}{l}\text { Range of } \\
\text { volume }\end{array}$} & \multirow{2}{*}{$\begin{array}{l}\text { Number of Sub- } \\
\text { catchments }\end{array}$} & \multicolumn{2}{|c|}{ Corresponding area } & \multicolumn{2}{|c|}{ Total of volume } \\
\hline & & Area & $\begin{array}{c}\text { Percentage } \\
\text { of area }\end{array}$ & $\begin{array}{l}\text { Volume } \\
\text { per year }\end{array}$ & $\begin{array}{l}\text { Percentage } \\
\text { of volume }\end{array}$ \\
\hline Discharge (CMS) & & $\left(\mathrm{km}^{2}\right)$ & $(\%)$ & (CMS) & $(\%)$ \\
\hline $0-3$ & 11 & $1,315 \cdot 7$ & 39.3 & 7.9 & $4 \cdot 7$ \\
\hline $3-6$ & - & - & - & - & - \\
\hline $6-9$ & 1 & 370.3 & 11.0 & 7.7 & 4.6 \\
\hline $9-12$ & 2 & 378.2 & 11.3 & 22.4 & 13.4 \\
\hline $12-15$ & 2 & 212.4 & 6.3 & 29.5 & 17.7 \\
\hline $15-20$ & 6 & $1,074.8$ & 32.1 & 99.1 & 59.5 \\
\hline Total & 22 & $3,351.3$ & 100.0 & 166.5 & 100.0 \\
\hline Sediment yield (Tons) & & $(\mathrm{km} 2)$ & (\%) & (Tons) & (\%) \\
\hline $0-1,000$ & 6 & 781.0 & $2,809.4$ & $23 \cdot 3$ & 5.6 \\
\hline $1,000-2,000$ & 4 & 630.4 & $6,424.0$ & 18.8 & 12.9 \\
\hline $2,000-3,000$ & 5 & 915.8 & $13,838.0$ & $27 \cdot 3$ & 27.8 \\
\hline $3,000-4,000$ & 5 & 736.0 & $18,043 \cdot 5$ & 22.0 & 36.3 \\
\hline $4,000-5,000$ & 2 & 288.1 & $8,654.0$ & 8.6 & 17.4 \\
\hline $5,000-6,000$ & - & - & - & - & - \\
\hline Total & 22 & $3,351.3$ & $49,768.9$ & 100.0 & 100.0 \\
\hline
\end{tabular}

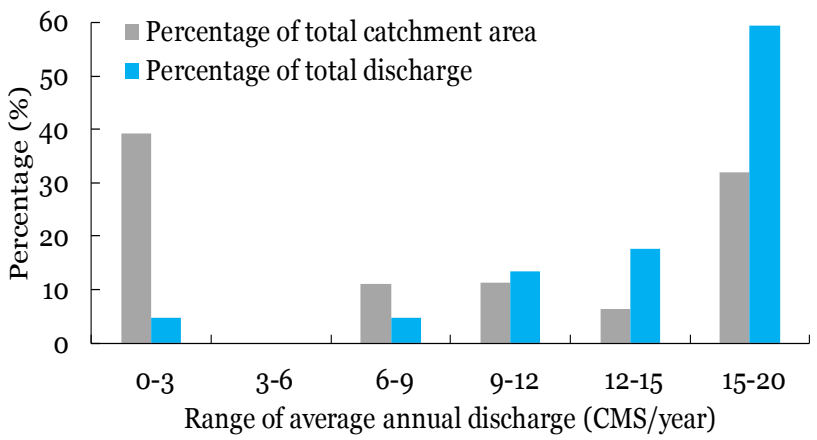

(a)

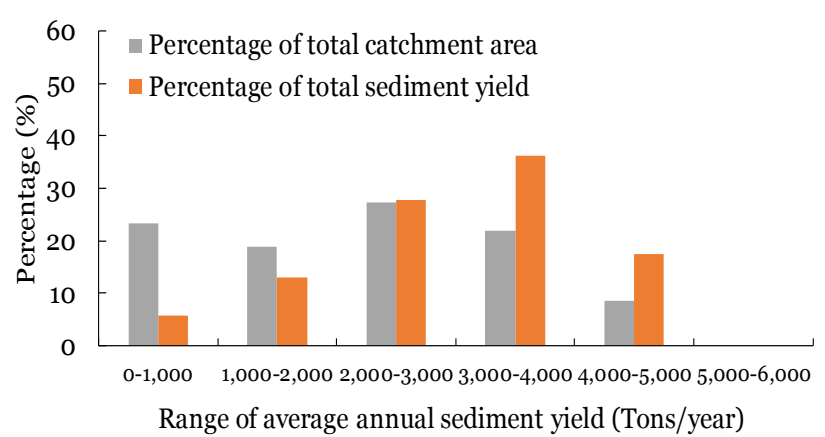

(b)

Figure 6. Comparison of percentage between sub-catchment areas with (a) discharge and (b) sediment yield divided by quantity range in the wet season 
By mainly analyzing the relationship and similarity between the area and both averages (discharge and sediment yield) found in the wet season, any sub-catchments all together producing the closet value or more than $50 \%$ of the total area could increase over $80 \%$ of the total discharge so the result from this study revealed that $49.7 \%$ of the subcatchments gave $90.6 \%$ of the total annual discharge average; meanwhile, $57.9 \%$ of the total area could produce $81.5 \%$ of the total sediment yield. Both values demonstrated the spatial distribution in which the sub-catchments with moderate and high averages were mainly located in the central part and the north of the main catchment. This assessment firmly indicated that more than $50 \%$ of the subcatchments within the Huay Luang Catchment had its potential to produce more than $90 \%$ of the discharge. Still, it also caused more than $80 \%$ of sediment yields. Accordingly, the discharge and sediment yield at the downstream should be managed systematically.

\section{CONCLUSION}

When applying the SWAT model with spatial data for the discharge and sediment yield estimation in the Huay Laung Catchment, the data from the Kh103 Station during 2008-2016 was calibrated and validated, and 12 sensitivity parameters with an impact on the discharge and sediment yields were analyzed by SWAT-CUP with SUFI-2 optimization technique to define the optimal sensitivity parameters for the model modification and to gain similar result as the real values. During the calibration and validation periods, the monthly of $\mathrm{R}^{2}$ and NSE are respectively 0.79 and 0.77 which were "good" for the discharge and 0.68 and 065 which were "satisfactory" for the sediment yields. In term of PBIAS, both were proved to be lower than the observed, so they were negative. Namely, the discharge was $-18.1 \%$ and the sediment yield was $-\mathbf{2 2 . 7 \%}$ which were "good" and "satisfactory" consecutively.

The highlight of the SWAT model used in this study was a watershed delineation process that classifies the Huay Luang Catchment into several sub-catchments and the 22 subcatchments were studied. At this point, the difference in the discharge averages in those sub-catchments were in a range from 0.05-18.1 CMS per year while the sediment yield averages could be $0-4,136.8$ tons per year. Besides, after considering the area size in the wet season with maximum discharge and sediment yield, more than $50 \%$ of the subcatchments area could produce $90 \%$ of the discharge and $82 \%$ of sediment yields, respectively. Notably, these high averages were mostly found in the northeast and the north since it was the catchment outlet. This finding was very contributive to this study since it helped simulate the discharge and sediment yield averages and presented them as the spatial distribution processed through the Geographic Information System (GIS) in the ArcGIS. Hence, it was possible to observe a sensitive area without observed gauge station and with unknown data that may cause a problem for the responsible organization or stakeholders in managing the water resource around the main catchment.

In summary, the research methodology and outcomes from the discharge and sediment yield evaluation using the SWAT model was expected to be greatly contributive to the making of future water resource management plan in both qualitative and quantitative approaches such as the assessment on the flood and drought risk, improvement of water quality for consumption, the environmental conservation for the Huay Luang Catchment or other regional catchments with similar physical features, as well as any catchments with insufficient measuring instrument and observed station for better performance through the sustainable collaboration amongst all related sector.

\section{ACKNOWLEDGEMENT}

The researcher would like to thank the Civil Engineering Department, Faculty of Engineering, Rajamangala University of Technology Isan (RMUTI), Khon Kaen Campus, for the research instruments and laboratory support for this research. Above all, the researcher also owed a debt of gratitude to the Land Development Department, the Thai Meteorological Department and the Regional Irrigation Office 6 (Khon Kaen), Royal Irrigation Department of Thailand, for the useful data for this research. 


\section{REFERENCES}

Abbaspour, KC, Rouholahnejad, E, Vaghefi, S, Srinivasan, R, Yang, H \& Klove, B 2015, 'A Continental-scale hydrology and water quality model for Europe: calibration and uncertainty of a high-resolution large-scale SWAT model', Journal of Hydrology, vol. 524, pp. 733-752.

Abbaspour, KC, Yang, J, Maximov, I, Siber, R, Bognerb, K, Mieleitner, J, Zobrist, J \& Srinivasan, R 2007, 'Modelling hydrology and water quality in the pre-alpine/alpine Thur watershed using SWAT', Journal of Hydrology, vol. 333, pp. 413-430. doi:10.1007-/s40710-015-0064-8.

Ali, AF, Cun-de, X, Xiao-peng, Z, Adnan, M, Iqbal, M \& Khan, G 2018, 'Projection of future streamflow of the Hunza River Catchment, Karakoram Range (Pakistan) using HBV hydrological model', Journal of Mountain Science, vol. 15, no. 10, pp. 2218-2235.

Arnold, AG, Srinivasan, R, Muttiah, RS \& Williams, JR 1998, 'Large area hydrological modeling and assessment part I: model development', Journal of American Water Resource Association, vol. 34, no. 1, pp. 73-89.

Ayivi, F \& Jha, MK 2018, 'Estimation of water balance and water yield in the Reedy Fork-Buffalo Creek Watershed in North Carolina using SWAT', International Soil and Water Conservation Research, vol. 6, pp. 203-213.

Azari, M, Moradi, HR, Saghafian, B \& Faramarzi, M 2016, 'Climate change impacts on streamflow and sediment yield in the North of Iran', Hydrological Sciences Journal, vol. 61, no. 1 , pp. $123-133$.

Cai, T, Li, Q, Yu, M, Lu, G, Cheng, L \& Wei, X 2012, 'Investigation into the impacts of land-use change on sediment yield characteristics in the upper Huaihe River catchment, China', Physics and Chemistry of the Earth, vol. 53-54, pp. 1-9.

Dagbegnon, C \& Sohoulande, D 2018, 'Assessment of sediment inflow to a reservoir using the SWAT model under undammed condition: a case study for the Somerville Reservoir, Texas, USA', Journal of International Soil and Water Conservation Research, vol. 6, pp. 222-229.

Devi, GK, Ganasri, BP \& Dwarakish, GS 2015, 'A review on hydrological models', Aquatic Procedia, vol. 4, pp. 10011007.

Djebou, DCS 2018, 'Assessment of sediment inflow to a reservoir using the SWAT model under undammed condition: a case study for the Somerville Reservoir, Texas,
USA', Journal of International Soil and Water Conservation Research, vol. 6, no. 3, pp. 222-229.

Faiza, H, Mohamed, M, Gil, M, Salaheddine, A \& Abdelkader, $\mathrm{K}$ 2018, 'Modeling of discharge and sediment transport through SWAT model in the Catchment of Harraza (Northwest of Algeria)', Journal of Water Science, vol. 32, pp. 79-88.

Faksomboon, B \& Thangtham, N 2017, 'Application of SWAT model for studying land use changes on suspended sediment in Upper Tha Chin watershed', Journal of SWU Science, vol. 33, pp. 124-139.

Food and Agriculture Organization of the United Nations (eds) 2006, Guidelines for soil description, 4th edn, Publishing Management Service Information Division, FAO, Rome, Italy.

Ganasri, BP \& Ramesh, H 2016, 'Assessment of soil erosion by RUSLE model using remote sensing and GIS - a case study of Nethrathi Catchment', Geoscience Frontiers, vol. 7, no. 6, 953-961.7(special issue), pp. 72-84.

Ghani, NAAA, Tholibon, DA \& Ariffin, J 2019, 'Robustness analysis of model parameters for sediment transport equation development', ASM Science Journal, vol. 12. doi: 10.32802/asmscj.2019.268.

Hosseini, SH \& Khaleghi, MR 2020, 'Application of SWAT and SWAT-CUP software in simulation and analysis of sediment uncertainty in semi-arid watersheds (case study: the Zoshk-Abardeh watershed)', Modeling Earth System and Environment. doi: 10.1007/s40808-020-00846-2.

Huang, TCC \& Lo, KFA 2015, 'Effects of land use change on sediment and water yields in Yang Ming Shan National Park, Taiwan', Environments, vol. 2, pp. 32-42. doi:10.3390/environments2010032.

Khalid, K, Ali, MF, Rahman, NFA, Mispan, MR, Haron, SH, Othman, Z \& Bachok, MF 2016, 'Sensitivity analysis in watershed model using SUFI-2 algorithm', Procedia Engineering, vol. 162, pp. 441-447.

Khelifa, WB, Hermassi, T, Strohmeier, S, Zucca, C, Ziadat, F, Boufaroua, M \& Habaieb, H 2017, 'Parameterization of the effect of bench terraces on runoff and sediment yield by SWAT dodeling in a small semi-arid watershed in Northern Tunisia', Land Degradation and Development, vol. 28 pp. 1568-1578.

Larsen, MAD, Refsgaard, JC, Drews, M, Butts, MB, Jensen, KH, Christensen, JH \& Christensen, OB 2014, 'Results from 
a full coupling of the HIRHAM regional climate model and the MIKE SHE hydrological model for a Danish catchment', Hydrology and Earth System Science, vol. 18, pp. 1-14.

Maalim, FK, Assefa, M, Melesse, AM, Belmont, P \& Gran, KB 2013, 'Modeling the impact of land use changes on runoff and sediment yield in the Le Sueur watershed, Minnesota using GeoWEPP', Catena, vol. 107, pp. 35-45.

Mango, LM, Melesse, AM, McClain, ME, Gann, D \& Setegn, SG 2011, 'Land use and climate change impact on the hydrology of the upper Mara river catchment, Kenya: result of modeling study support better resource management' Hydrology and Earth System Science, vol. 15, pp. 22452258.

Noh, S, Choi, M, Jung, K \& Park, J 2019, 'Prospect of discharge at Daecheong and Yongdam dam watershed under future greenhouse gas scenarios using SWAT model', Engineering Journal, vol. 23, no. 6, pp. 469-476.

Nourani, V, Roughani, A \& Gebremichael, M 2011, 'TOPMODEL capability for rainfall-runoff modeling of the Ammameh watershed at different time scales using different terrain algorithms', Journal of Urban and Environmental Engineering, vol. 5, no. 1, pp. 1-4.

Oubeidillah, AA, Kao, SC, Ashfaq, M, Naz, BS \& Tootle, G 2014, 'A large-scale, high-resolution hydrological model parameter data set for climate change impact assessment for the conterminous US', Hydrology and Earth System Science, vol. 18, pp. 67-84.

Parsakhoo, A, Lotfalian, M, Kavian, A \& Hosseini, SA 2014, 'Prediction of the soil erosion in a forest and sediment yield from road network through GIS and SEDMODL', International Journal of Sediment Research, vol. 29, pp. 118-125.

Petsountang, O \& Jirakajonhkool, S 2012, 'Integration GIS and MUSLE to evaluation of runoff and sediment yield in watershed Wang Saphung, Loei Province', Thai Journal of Science and Technology, vol. 1, no. 2, pp. 96-108.

Roslee, R \& Sharir, K 2019, 'Integration of GIS-based RUSLE model for land planning and environmental management in Ranau Area, Sabah, Malaysia', ASM Science Journal, vol. 12, no. 3, for ICST2018, pp. 60-69.

Sajikumar, N \& Remya, RS 2015, 'Impact of land cover and land use change on runoff characteristics', Journal of Environmental Management, no. 161, pp. 460-468.

Son, NT, Binh, ND \& Shrestha, RP 2015, 'Effect of land use change on runoff and sedimentation yield in Da River Catchment of Hoa Binh Province, Northwest Vietnam', Journal of Mountain Science, vol. 12, no. 4, pp. 1051-1064.
Sriworamas, K, Prasanchum, H \& Supakosol, J 2020, 'The effect of forest rehabilitation on runoff and hydrological factors in the upstream area of the Ubolratana Reservoir in Thailand', Journal of Water and Climate Change, vol. 11, no. 4, pp. 1009-1020.

Vidula, S \& Sushma, K 2017, 'Application of SWAT model to investigate soil loss in Kaneri watershed', International Journal of Earth Sciences and Engineering, vol. 10, no. 02, pp. 207-213. doi: 10.21276/ijee.-2017.10.0211.

Vojinovic, Z \& Abbott, MB 2017, 'Twenty-five years of hydroinformatics', Water, vol. 9, no. 59. doi: 10.3390/w9010059.

Worku, T, Khare, D \& Tripathi, SK 2017, 'Modeling runoffsediment response to land use/land cover changes using integrated GIS and SWAT model in the Beressa watershed', Environmental Earth Sciences, vol. 76 no. 550, doi: 10.1007/s12665-017-6883-3.

Wuttichaikitcharoen, P \& Babel, M 2014, 'Principal component and multiple regression analyses for the estimation of suspended sediment yield in ungauged cathcments of Northern Thailand', Water, vol. 6, no. 8, pp. 2412-2435.

Xia, X, Liang, Q \& Ming, X 2019, 'A full-scale fluvial flood modelling framework based on a high-performance integrated hydrodynamic modelling system (HiPIMS)', Advances in Water Resources, vol. 132, doi: 10.1016/j.advwatres.2019.103392.

Yang, Y, Yang Y, Han, S, Macadam, I \& Liu, DL 2014, 'Prediction of cotton yield and water demand under climate change and future adaptation measures', Agricultural Water Management, vol. 144, pp. 42-53.

Yang, J, Reichert, P, Abbaspour, K, Xia, J \& Yang, H 2008, 'Comparing uncertainty analysis techniques for a SWAT application to the Chaohe Catchment in China', Journal of Hydrology, vol. 358, pp. 1-23.

Zardari, HZ, Naubi, IB, Abbasi, SA, Jamali, KA \& Miano, TF 2019, 'An improved method for watershed management a case study of Arcgis application to Skudai Watershed, Malaysia', International Journal of GEOMATE, vol. 17, no. 64, pp. 145-151.

Zhang, L, Meng, X, Wang, H \& Yang, M 2019, 'Simulated runoff and sediment yield responses to land-use change using the SWAT Model in Northeast China', Water, vol. 11, no. 5, pp. 915. doi: 10.3390/w11050915.

Zhang, S, Li, Z, Lin, X \& Zhang, C 2019, 'Assessment of climate change and associated vegetation cover change on 
watershed-scale runoff and sediment yield', Water, vol. 11, pp. 1-20, doi: 10.3390/w11071373.

Zuo, D, Xu, Z, Yao, W, Jin, S, Xiao, P \& Ran, D 2016, 'Assessing the effects of changes in land use and climate on runoff and sediment yields from a watershed in the Loess Plateau of China', Science of the Total Environment, vol. 544, pp. 238-250. 